Application Patterns of Life Cycle Assessment in Selected European Countries

\section{LCA Goes Business}

\section{Wie kann eine Ökologisierung von Produkten und Dienstleistungen erreicht werden? Eines der vielversprechendsten Instrumente sind Öko-Bilanzen, die die Umweltwirkungen über den kompletten Lebensweg von Produkten in die Bewertung mit einbeziehen. Während bisher die methodische Diskussion im Vordergrund stand, hat ein europäisches Forschungsprojekt erstmals den} Schwerpunkt auf die Anwendung und Implementation des Instruments in Unternehmen gelegt (1). Betrachtet wurden die Länder Deutschland, Italien, Schweden und die Schweiz. Die wichtigsten Ergebnisse liegen nun vor.

$\mathrm{T}$ Von Paolo Frankl und Frieder Rubik he challenge of our times is the greening of products and services. Different tools, concepts and ideas to support this have been developed in the last 20-30 years. Life Cycle Assessment (LCA) is perceived as a fascinating and sophisticated tool for an ecologisation of business and economy (2). Past research on LCA was and still is focused on improving the methodology. As a result, during the last 5-10 years „LCA-technique“ has improved considerably. However, the embodiment of LCA into the application context has nearly not been stressed; this is a new challenge which was examined by us in four selected countries: Germany, Italy, Sweden and Switzerland.

The research project had the following four main objectives, namely: i) to make a comprehensive inventory of LCA applications; ii) to examine the role of LCA techniques within business decision making; iii) to identify the factors influencing this role negatively and positively (barriers and opportunities) and iv) to examine the links of business decisions-making with implications for environmental policy and analyse the relevance of LCA for environmental policy. We used a set of four approaches for obtaining empirical data:

- An inventory of LCA studies allowed us to get a broad overview of who uses LCA in which country. The information gained includes data on the yearly evolution of number of LCA studies and the commissioners.

- A survey on the applications of LCA was carried out in 1997. It gives a static picture of how LCA is used in the different countries. It is based on 382 returned questionnaires (of 1625 sent out).

20 case-studies allowed a in-depth analysis of the use of LCA by business and industry. They confirmed the results of the survey and allowed us to understand the dynamic process of introduction of LCA in a company.

- Interviews with policy and public administration people and an analysis of available policy documents.

\section{Application trends of LCA}

The level of diffusion of LCA in the four countries is different. In absolute numbers; Germany showed the highest level of studies carried out. However, if this number is normalised both with respect to population and GDP, then Sweden presented as the country in which LCA is used most. The „level" of use and application trends of LCA in the four countries can be shortly summarised as follows (3):

Germany has a long-standing tradition in LCA. There is a considerable interest in LCA, both in business and in the political milieus. However, there are some misunderstandings and different visions: The confrontation policy-business particularly refers to the role which LCA should play in the field of environmental policy; whereas business refuses such a role, environmental policy makers support it. As a consequence, a lot of debates and mistrust arose. Nevertheless, especially larger companies are very engaged in LCA, but the main focus is still a rather retrospective one (LCA is rather used for learning and/or confirmation of previous results). In general, German companies believe in a future increase of LCA activities (4).

The situation in Italy might be described as a good beginning. The knowledge and diffusion of LCA began just recently. In many cases, international mother corporations triggered LCA studies. However, the situation seems to be evolving quickly. The numbers of studies and of compa- nies involved in LCA are both increasing. Most involved companies are developing internal LCA teams and know-how, and are optimistic about the future of LCA. There is a problem with Small and Medium Enterprises (SME), which have less motivation and resources for carrying out LCA. However, Italy is in the process of founding an Italian Association for LCA which will include representatives of business, public administration, universities, research institutes, and NGOS. Its objective will be to tackle methodology and data issues and to reinforce communication and collaboration between companies, between business and policy, and between business and the research world.

Sweden is the country among the four selected where LCA is most developed and used. This appears due to, amongst other things, a high level of environmental awareness in society, the proactive behaviour of companies, and a ,cultural" tradition of collaboration between business and research. In addition, the relationship between business and public administration is very positive. On one hand, there is little intervention in the sense of command \& control, on the other hand there is a high level of communication. Sweden had the highest share of LCA carried out internally in firms, and the highest share of companies which expected an increased use of LCA in the future.

Switzerland shows the second highest number of LCA studies per GDP unit (close to Sweden, and four times higher than Germany). There is certainly substantial experience of LCA in this country; the public sector has been an important commissioning body. The survey indicated a more pro-active tendency of companies to apply LCA to compare existing products with possible alternative ones. However, some saturation effects can be also observed. This result is shown both in the case-studies and, more significantly, in the survey.

\section{The process of institutionalisation}

How are new norms and methods - as LCA spread in industry? Before they can be used as a routine-tool for the solution to existing problems, a process going through certain stages has to take place. A possible theoretical background for explaining this is the institutionalisation theory, which analyses institutionalisation processes within the external control perspective. Tolbert/Zucker describe that the process of 
Figure 1: Classification of companies according to the level of institutionalisation of LCA

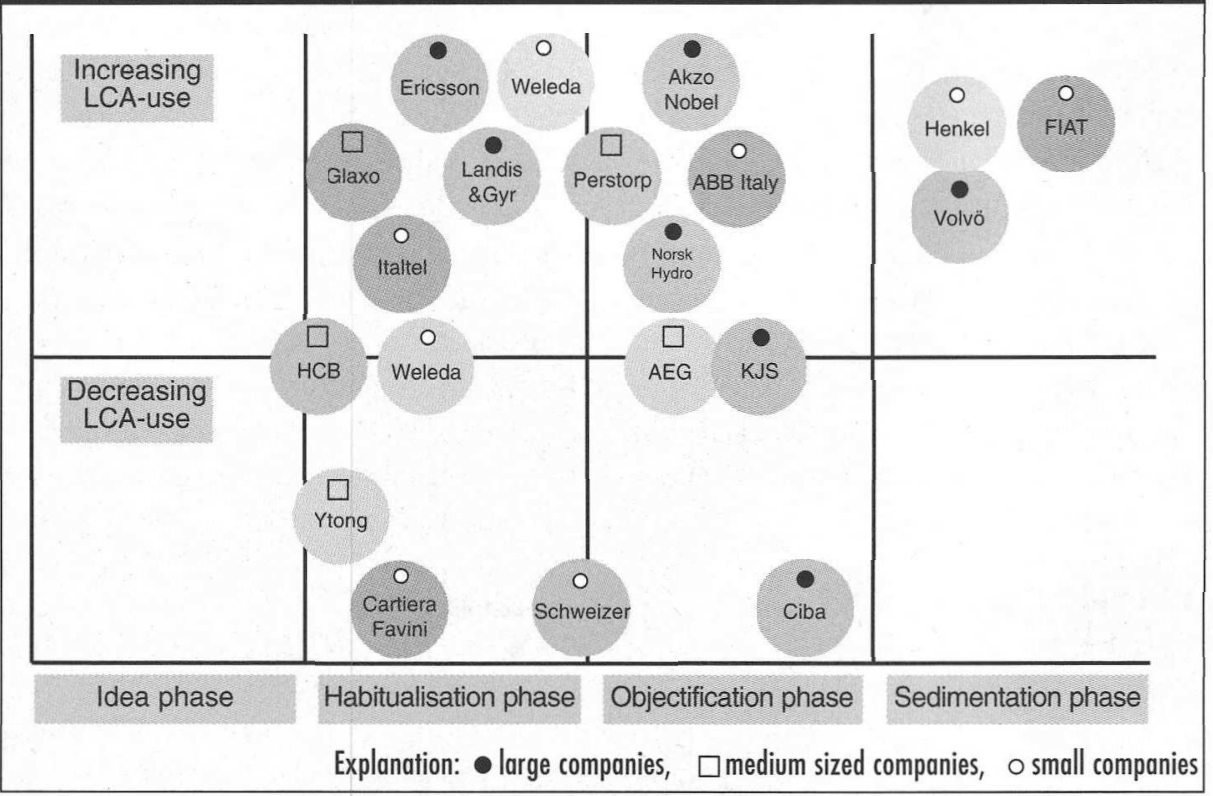

Source: adapted from Frankl/Rubik (see reference 1)

adaption to new situations, requirements etc. pursues an institutional „script“ with different phases in the introduction of a new phenomenon until it becomes something taken for granted and routine:

\section{Innovation}

2. Habitualisation: It involves the development of patterned problem-solving behaviours and the identification of signals for when to apply the problem-solving behaviour.

3. Objectification: It involves the development of a consensus regarding the problem-solving behaviours.

4. Sedimentation: It is characterised by the cessation of promoting and accumulating evidence and by the existence of a formal structure spread across the group of actors theorised to be the appropriate adopters (5).

This theoretical framework was applied by us to the process of analysing the adoption of business to LCA (see figure 1). It is able to explain successes and/or failures in the introduction of LCA in business.

\section{Similar cross-country patterns}

We observed that this process follows similar patterns in all countries. Of course, the boundary conditions are different from country to country, however the process can be described in the same way. In this context, we stress the key importance of actors and subjective factors (in particular, the presence and influence of a champion - or entrepreneur - who pushes LCA activities within the company). Another crucial point is the organisational context. In particular, for a full institutionalisation process, good internal communication channels are very important. The starting of LCA activities can occur both in a top-down or bottom-up approach. This is not significant for the further success of the institutionalisation process. Other factors are important, particularly during the second stage of gst these, there is a need to obtain the consensus or the mandate of top-management at that stage. External consultants might be a positive trigger for starting LCA activities in a company. However, afterwards, an internal know-how has to be developed and LCA activities preferably to be carried out internally. Relying only on external consultants might rather be an obstacle and lead to failure of LCA activities. This result is both confirmed by the survey and the case-studies. All successful cases show established internal LCA teams and know-how. All companies relying only on external consultants faded out LCA activities.

The role of LCA changes over time during the different institutionalisation stages. At the beginning, usually the role of LCA is for learning/confirming and is not too important. However, during the objectification stage it becomes crucial. Indeed, whatever the exact role in terms of application, LCA has to have a good justification for it. This is absolutely needed to create consensus within the company. In all cases where a good justification was missing LCA activities had an uncertain future or were stopped. institutionalisation, namely objectification. Amon-

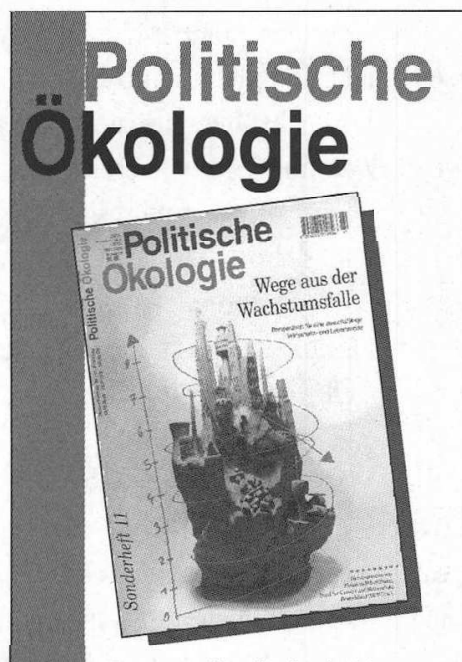

Sonderheft 11

Wege aus der Wachstumsfalle

Hrsg. von Heinrich-Böll-Stiftung und BUND Deutschland e.V.

Tn Zeiten der MassenarbeitslosigIkeit und einer dramatischen Finanzierungskrise der öffentlichen Haushalte gewinnt das alte Rezept vom Wirtschaftswachstum wieder eine herausragende Bedeutung. Kaum ein Wahlprogramm, ein Leitartikel oder eine Konferenz, die Wachstum nicht als Allheilmittel preisen. Doch kann es wirklich die Erwartungen erfüllen, die alle erhoffen? In Sonderheft 11 der Politischen Ökologie diskutieren renommierte Autoren unterschiedlichster Herkunft die ökonomischen und sozialen Folgen des Wirtschaftswachstums aber auch Alternativen.

R. Fücks: Die Chancen des „weniger" - A. Zahrnt: Wirtschaftswachstum taugt nicht als politisches Programmm - C. Amery: Die Kulturgeschichte offenbart die Wachstumsgrenzen - R. Loske: Die GRÜNEN und das Wirtschaftswachstum . J. Huber: Die Konsistenz-Strategie . J. Priewe: Wachstum und Nachhaltigkeit - L. Reisch: Nachhaltiger Konsum - A. Brandhorst: Soziale Gerechtigkeit jenseits des Wachstums . S. Narain: Die Perspektive des Südens . E. Hildebrandt: Weniger Erwerbsarbeit - mehr Wohlstand? . H. C. Binswanger: Die Magie des Geldes - V. Hösle: Nettowohlstand statt Bruttosozialprodukt

ausführliche Inhaltsangaben aller Ausgaben finden Sie auch auf unserer Internetseite: http://www.oekom.de

- ökom $\mathrm{GmbH}$

- Waltherstr. 29, Rgb.

- 80337 München

- Tel.: 089/544 184-0;

- Fax: 089/544 184-99

- http: //www.oekom.de 
In particular, a major point is the perceived influence on the rest of the product life-cycle. If companies perceive that they have no or limited influence, they do not see any interest anymore in carrying out time-, money- and resource consuming LCA studies. In its turn, this perceived influence depends on several factors, such as size, sector, position in the product life-chain and structure of the company itself.

\section{- Insufficient marketing potential}

In the past, especially in Germany, there have been great expectations about the use of LCA for marketing. However, a main observation is that the expectations about the use of LCA for marketing could not be satisfied. In many cases, marketing had been the early motivation for starting LCA, but companies had quickly to realise that today LCA cannot be used for marketing (yet). This is mainly connected to methodological issues, which often render results disputable. Another problem is to summarise in a simple way for the public the results of a complex study, which always includes important assumptions, and often subjective valuation factors.

For the future, we do not exclude that LCA might be used for marketing. In the long-term, companies may want to develop a tool which is able to provide economically tangible, short-term benefits. However, this requires the maximum of transparency and clear rules for simplification procedures, reporting, definition of system boundaries, all kind of assumptions made, impact assessment methodologies, etc.

\section{LCA for learning}

At present, perhaps the highest value of LCA is for learning. Our research indicates that benefits of LCA are generally long-term. The clearest example of learning is the shift from external (marketing) motivations and unsatisfied expectations towards internal decision-making. The survey shows that the main applications of LCA are identification of bottlenecks and research \& development activities. In our case-studies, we observed that where a learning process happened, this could lead to:

- A change in the internal organisation,

the shift from the expected marketing use to internal applications,

spin-offs (energy and materials saving, bottleneck identification, etc.),

development of simplified/alternative methodologies, and a collaborative attitude.

The translation of the results of the learning process into action can be either direct or indirect coming out from a learning cycle. The benefits of LCA are rather long-term ones. This carries the implication that there is a generally high acceptance of integration of LCA results for long-term planning (strategic decisions, next cycle of investments, etc.). In the short term, LCA results are translated into action only if they lead to win-win situations (e.g. if they imply also cost-savings). In general, in the short-term economic aspects always prevail.

\section{Implications for policy}

The results from our survey showed - confirmed by the case-studies - that the role of policy pressure is regarded as of minor importance in the adoption of LCA practice in companies. Major drivers for starting ICA noted were, amongst others, cost saving opportunities, product related environmental problems and emerging green markets.

On the other hand, if required, LCA is generally considered as a suitable tool to respond to external pressure from regulation, and to anticipate legislation. We observed that several companies introduced LCA due to company-external discussions and pressures (existing, expected or perceived).

Moreover, policy can support LCA activities in either direct or more indirect ways. Examples of direct support are green public purchasement and the financing of LCA studies. However, the likely most important support is indirect: Policy can be very effective in developing public life-cycle inventory data-bases, supporting eco-labels, supporting ISO activities, collaborating with business for solving methodological issues (i.e. related to impact assessment). This kind of help is generally well accepted by companies. On the contrary, they strongly mistrust the possible use of LCA as a basis for command \& control policy measures. Our general conclusion about the relationship between policy and business is that a new age of communication and co-operation should start. A good culture of communication is present particularly in Sweden. On the other hand, especially in Germany and Italy, business and policy should come closer together.

In general, more collaboration is stringently needed for a successful and effective diffusion of LCA. Collaboration is a must within a single company: Different departments, actors and champ- ions have to communicate with each other, to support each other and try to learn together from LCA. A reasonable result might be successful learning and at the very end a decision to continue with LCA activities. Besides that, a second type of collaboration is required in the supply-chain, where upstream and also downstream collaboration is necessary to exchange environmental information and also to agree on measures to improve the eco-profiles of products. A third type of very valuable collaboration form is the exchange of ideas, opinions and experiences among researchers and practitioners.

\section{References}

(1) The study "The use of LCA in business decision-making processes and its implications for environmental policy" was carried out with financial support of the European Commission (DG XII) within the "Climate and Environment"-Programme. The co-ordinator of the whole project was IÖW; further contractors were Istituto di Ricerche Ambiente Italia in Milano, Gothenburg Research Institute in Gothenburg, Institute for Prospective Technological Studies in Seville and ökoscience AG in Zürich.

The whole report will be published later this year: Frankl, Paolo/ Frieder Rubik: Life Cycle Assessment in Industry and Business - Adoption Patterns, Applications and Implications. Heidelberg: Springer 1999.

(2) For a broad discussion of the instrument see Ökologisches Wirtschaften 6/97.

(3) Further details are presented in: Frankl, Paolo/Frieder Rubik: Application Patterns of Life Cycle Assessment in German, Italian, Swedish and Swiss Companies. Comparative Results and Conclusions. IÖW-Schriftenreihe 130/98, Berlin.

(4) Frieder Rubik: Application Patterns of Life Cycle Assessment within German Companies. Results and Conclusion of a Survey. IÖW-Schriftenreihe 129/98, Berlin.

(5) Tolbert, Pamela S./ Lynne G. Zucker: The Institutionalization of Institutional Theory. In: Clegg, S.R./ C. Hardy/ W.R. Nord (Eds.): Handbook of Organization Studies. London: Sage 1996, p. 175-190.

\section{Die Autoren}

Dr. Paolo Frankl is researcher at the Istituto di Ricerche Ambiente Italia, c/o Ecobilancio s.r.l, Via Nomentana 257, 1-00161 Rome, Italy; Tel. 0039-06-44239034, Fax 0039-06-44265063; E-mail: ecobil@cambio.it

Frieder Rubik is researcher at the löW, regional office Baden-Württemberg, Bergstrafle 7, 69120 Heidelberg; Tel. 06221/649160, Fax 06221/ 27060;

E-mail: Frieder:Rubik@heidelberg.ioew.de 
(c) 20I0 Authors; licensee IÖW and oekom verlag. This is an article distributed under the terms of the Creative Commons Attribution Non-Commercial No Derivates License (http://creativecommons.org/licenses/by-nc-nd/3.o/), which permits unrestricted use, distribution, and reproduction in any medium, provided the original work is properly cited. 